\title{
Preface: Special Issue in Honor of Lewis Rambo
}

\author{
Nathan Carlin ${ }^{1} \cdot$ Robert C. Dykstra ${ }^{2} \cdot$ Ryan LaMothe $^{3}$ \\ Published online: 13 July 2020 \\ C Springer Science+Business Media, LLC, part of Springer Nature 2020
}

The Group for New Directions in Pastoral Theology held a special conference at Zephyr Point Presbyterian Conference Center on Lake Tahoe from September 8-11, 2019, for the purpose of honoring Lewis Rambo, editor of Pastoral Psychology. Lewis attended the conference with his wife Judy Sha He. In all, there were 22 participants, some presenting papers and others joining in the discussions. The Group for New Directions in Pastoral Theology wanted to honor Lewis in this way for his support over its lifetime in his providing space for our conference papers in the journal and for his work as editor since 1984. At the meeting, Kathy McKay, copyeditor for the journal, presented Lewis with a beautiful commemorative plaque, provided by Springer, as a small token of our gratitude to him. The articles in this special edition reflect the conversations we enjoyed over four idyllic days overlooking beautiful Lake Tahoe.

Born in Stephenville, Texas, on December 29, 1943, Lewis Ray Rambo grew up in Comanche, Texas, the hometown of his father. His mother raised him during his early years while his father served in World War II, stationed in the Philippines. He remembers that these years were difficult in part because his father was away but also, more profoundly, because the economy was so bad in those days. The family moved in Comanche various times, slowly climbing up the economic ladder.

His mother got serious about religion when Lewis was about five years old. He was raised in the Church of Christ and remains loosely affiliated with the denomination today. During his childhood, he experienced the Church of Christ as very committed to the Bible and seeming to him to be somewhat rigid, conservative, and exclusivist. But, as Lewis puts it, he "bought it, hook, line, and sinker." A key question for him throughout his childhood and into his young

Nathan Carlin

nathanscarlin@gmail.com

Robert C. Dykstra

robert.dykstra@ptsem.edu

Ryan LaMothe

rlamothe@saintmeinrad.edu

1 McGovern Center for Humanities and Ethics, McGovern Medical School, JJL 410, 6431 Fannin Street, Houston, TX 77030, USA

2 Princeton Theological Seminary, P.O. Box 821, Princeton, NJ 08542-0803, USA

3 Saint Meinrad Seminary and School of Theology, St. Meinrad, IN 47577, USA 
adult years was: "What must I do in order to be saved?" His father, a nominal Southern Baptist, seemed much more secure in his salvation, never converting to the Church of Christ. For as long as he can remember, Lewis wanted to be a minister, in a large part due to the influence of two pious uncles.

Lewis majored in Bible at Abilene Christian College (now Abilene Christian University) and felt very much at home there, as most of the students had also been raised in the Church of Christ and came from rural areas. His college years, for Lewis, were a time of expansion for him, especially relationally. His roommate for his first two years was from the Philippines. He also became very close with two Australian students. He recalls that most of his friends were international students who were involved with mission groups of the college. If Lewis's greatest contribution to Pastoral Psychology is that he made the journal truly international, both in terms of its Board and its contributors, the seeds of this global orientation were sown at Abilene.

Lewis recalls that in those days at Abilene there was a racist practice, if not actual policy, of African blacks being permitted to attend the college but not African Americans. This seemed wrong to Lewis, and he recalls talking with professors about this. A courageous Bible professor, Carl Spain, questioned the practice and was able to persuade the school to admit African Americans.

After college, Lewis moved to Reading, Pennsylvania, to serve as a minister. He continued to be interested in issues of racism and began reading the works of the Rev. Dr. Martin Luther King, Jr. One year after Lewis began his ministry there, King was assassinated. Lewis was deeply troubled by this and by the social unrest in the country, and so he wanted to preach a sermon on King's assassination and civil rights. His wife at that time advised against it on grounds that the church was too conservative. Lewis acquiesced to her wishes but decided to offer a pastoral prayer that addressed King's assassination. As it turns out, his wife was right: the congregation encouraged Lewis to leave. Fortunately, this experience led him to realize that a B.A. in Bible was insufficient to be a qualified minister.

Lewis then decided to attend Yale Divinity School for a Master of Divinity degree. There, he was introduced to pastoral theology via James Dittes. As a remarkable coincidence, Liston Mills was a visiting scholar at Yale that semester and served as the teaching assistant for Dittes's Introduction to Pastoral Care and Counseling course. In terms of the history of the discipline, it is a striking image to think of Lewis Rambo taking Introduction to Pastoral Care and Counseling from James Dittes and having Liston Mills as a teaching assistant. Dittes nurtured Lewis's psychological interests and encouraged him to take a course taught by George Mahl at Yale Medical School on the evolution of Sigmund Freud's thought. In addition, Lewis studied the development of Paul Tillich's thought with David Kelsey and works of Søren Kierkegaard with Paul Holmer.

After Yale, Lewis aspired to become a therapist. He applied to a number of programs in clinical psychology but was not accepted for admission. However, he was accepted at the time into the Religion and Psychological Studies doctoral program in the Divinity School of the University of Chicago. During his first two years at Chicago he was mentored by Donald Capps, who remained a lifelong friend. Donald Browning became Lewis's dissertation advisor, directing him to write on William James. He also took courses with other prominent intellectuals, including Victor Turner and Talcott Parsons, both of whom shaped Lewis's intellectual orientation toward integrating psychological, sociological, and anthropological perspectives.

In 1976, Lewis became an assistant professor of psychology at Trinity College in Deerfield, Illinois, teaching undergraduate students. He subsequently accepted a position at San 
Francisco Theological Seminary, where he spent the rest of his teaching career for a notable 32 years. He also taught during those years at the Graduate Theological Union in Berkeley and at the University of California, Berkeley, in psychology of religion. Lewis did a substantial amount of international teaching as well, including a course on conversion at Hebrew University in Jerusalem and various courses at Yonsei University in Seoul, South Korea, and Fudan University in Shanghai, China.

After retiring from teaching, Lewis and Judy typically began to spend eight months each year in California and four in China, for Judy is a native of Shanghai. If Lewis did not do much traveling as a child (because his father was glad to be home from the war), he certainly made up for it later in life. He continued as editor of Pastoral Psychology until deciding to step down in 2020 - thus serving in that role for a remarkable 36 years.

Lewis's chief intellectual contribution is concerned with religious conversion. Indeed, he created an unrivaled interdisciplinary model that continues to be cited by scholars in disciplines far beyond pastoral theology and psychology of religion. It is not an overstatement to say that Lewis is the world's leading scholarly expert on religious conversion. His core theory can be found in Understanding Religious Conversion (Rambo 1993), which he has updated and modified in various articles over the years (see, e.g., Rambo 1999, 2010; Rambo \& Bauman 2012). He also recently coedited, with Charles Farhadian, The Oxford Handbook on Religious Conversion (Rambo \& Farhadian 2014). Many of the articles in this issue engage Lewis's model.

Through his long service as editor of this journal, Lewis provided various related fieldspastoral psychology, pastoral theology, psychology of religion, and pastoral care and counseling - with the stability that academic disciplines need in order to flourish. We are so grateful for the space and guidance he has provided over the past decade for the Group for New Directions in Pastoral Theology, and we offer these papers as a festschrift to celebrate Lewis for his steadfastness, kindness, good humor, and intellectual and editorial vision.

\section{References}

Rambo, L. (1993). Understanding religious conversion. New Haven: Yale University Press.

Rambo, L. (1999). Theories of conversion: Understanding and interpreting religious change. Social Compass, 46(3), 259-271.

Rambo, L. (2010). Conversion studies, pastoral counseling, and cultural studies: Engaging and embracing a new paradigm. Pastoral Psychology, 59, 433-445.

Rambo, L., \& Bauman, S. (2012). Psychology of conversion and spiritual transformation. Pastoral Psychology, 61(5-6), 879-894.

Rambo, L., \& Farhadian, C. (Eds.). (2014). The Oxford handbook of religious conversion. New York: Oxford University Press.

Publisher's Note Springer Nature remains neutral with regard to jurisdictional claims in published maps and institutional affiliations. 